\title{
Metadata of the Regge \& Dinkel catchment for the MARS project
}

Lilith Kramer \& Marijn Kuijper
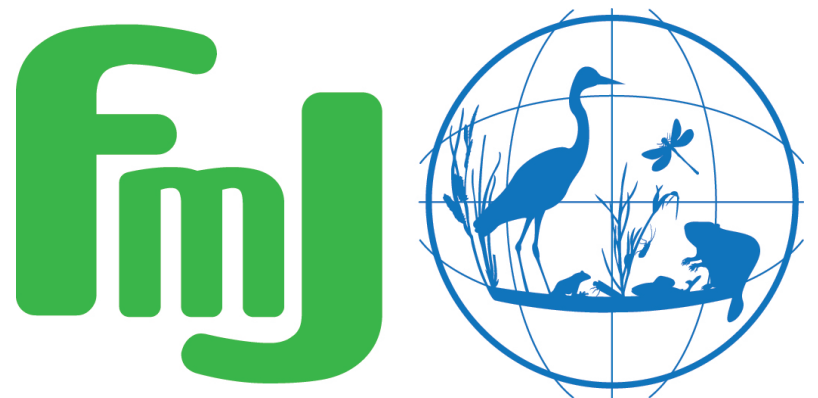

Freshwater Metadata Journal 



\section{Metadata of the Regge \& Dinkel catchment for the MARS project}

\section{Lilith Kramer \& Marijn Kuijper}

1 Deltares, Delft, The Netherlands

Please cite this paper as follows: Kramer L. \& Kuijper M., 2016. Metadata of the Regge \& Dinkel catchment for the MARS project. Freshwater Metadata Journal 19: 1-8. http://dx.doi.org/10.15504/fmj.2016.19

Received: 2016-05-23 / Published: 2016-12-23

\section{Keywords}

macrophytes, macrofauna, fish, physico-chemical parameters, Regge, Dinkel, Netherlands, streams, freshwater

\section{Short description of the dataset/summary}

This data set contains an overview of biological and environmental data from the Regge and Dinkel catchment, the Netherlands. The main factors that impact this catchment are hydrological alteration, groundwater abstraction and drainage, point source and diffuse nutrient loading.

The data has been collected between 2000 and 2012 by the waterboard Vechtstromen and contains macroinvertebrate, macrophyte, fish, and physico-chemical parameters. The dataset is available upon request from the waterboard Vechtstromen.

\section{General information}

dataset entry ID:

name of the dataset:

full name of the dataset:

type of dataset:

data type:

science keywords according to $\underline{\mathrm{GCMD}}$

topic:

keywords:

\section{MARS_17}

Regge \& Dinkel catchment (The Netherlands)

species (taxonomic group) per site database including environmental information

point data/observation data
Biosphere, Biological Classification, Terrestrial Hydrosphere macroinvertebrates, macrophytes, fish, physico-chemical parameters, streams, rivers, freshwater

ISO topic category according to ISO 19115: 


\section{Technical and administrative specifications}

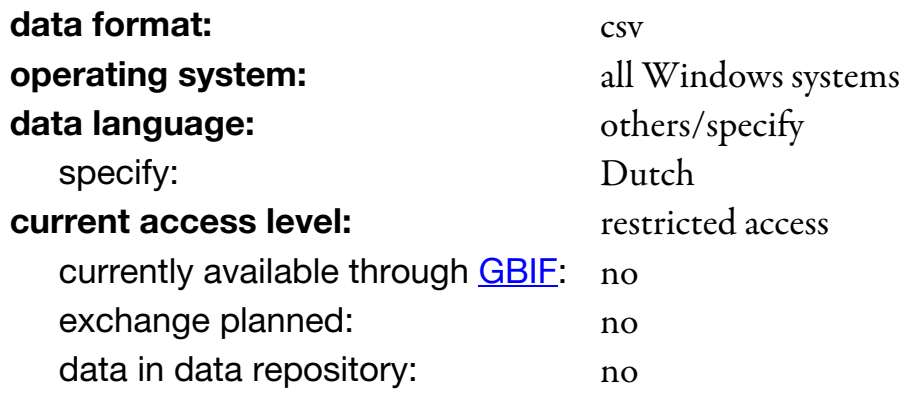

Do you plan to publish the data on the Freshwater Biodiversity Data Portal:

comments:

no

The data is public, but should be requested at the waterboard Vechtstromen, see https://www.vechtstromen.nl/algemeen (in Dutch).

update level:

others/details:

documentation:

type:

language:

specify:

contact details:

metadata contact person:

first, last name:

phone:

email:

institution:

address:

postal code, city:

province, state:

country

web address:

technical contact person:

first, last name:

phone:

email:

scientific contact person:

first, last name:

phone:

email: update planned

See river basin management plan:

http://www.vechtstromen.nl/waterbeheerplan/uitvoering/gebruiken-we-onze/ meten-monitoren/ (in Dutch)

internal description

others/specify

Dutch

Lilith Kramer

$+31883357367$

Lilith.Kramer@deltares.nl

Deltares

Boussinesqweg 1

2629 HV Delft

Zuid-Holland

The Netherlands

http://www.deltares.nl/

Lilith Kramer

$+31883357367$

Lilith.Kramer@deltares.nl

Lilith Kramer

+31883357367

Lilith.Kramer@deltares.nl

\section{Intellectual property rights and citation}

\section{dataset creator (data compiler):}

contact name:

contact email:

contact institution:
Waterschap Vechtstromen

info@vechtstromen.nl

Waterschap Vechtstromen 


\section{data contributors to/owners of this dataset:}

single

criteria for using this dataset: The dataset needs to be requested from dataset creator with specific conditions of use.

citation of this dataset:

author(s):

Waterschap Vechtstromen

title:

Macrofyten-, macrofauna- en visdata Dinkel stroomgebied 2000-2012

year:

2015

citation of the metadata:

author(s):

Kramer L. \& Kuijper M.

title and journal (name, number, pages):

Metadata of the Regge \& Dinkel catchment for the MARS project. Freshwater Metadata Journal 19: 1-8

year: $\quad 2016$

doi: $\quad$ http://dx.doi.org/10.15504/fmj.2016.19

\section{General data specifications}

regional coverage of the dataset:

scale of the dataset:

catchment

spatial extent (bounding coordinates):

southernmost latitude $\left[^{\circ}\right]$ :

$\mathrm{N} 52^{\circ} 05^{\prime} 00^{\prime \prime}$

northernmost latitude $\left[^{\circ}\right]$ :

$\mathrm{N} 52^{\circ} 29^{\prime} 00^{\prime \prime}$

westernmost longitude $\left[{ }^{\circ}\right]$ :

$\mathrm{E} 6^{\circ} 26^{\prime} 00^{\prime \prime}$

easternmost longitude $\left[{ }^{\circ}\right]$ :

E $7^{\circ} 08^{\prime} 00^{\prime \prime}$

countries:

Europe: Netherlands

world climatic regions according to Köppen:

Group C: temperate/mesothermal climates

freshwater ecoregions of the world (FEOW) according to WWF:

Europe: Central \& Western Europe

European ecoregions according to Illies (WFD):

ecosystem type:

covered timeframe:
Central Plains (ER14)

rivers, lakes/ponds

$2000-2012$

\section{Site specifications}

coordinate system/grid data:

datum (e.g. WGS84):

grid data available:

comments: latitude/longitude, format: DD

projected, local

EPSG:28992

no

The coordinate system used is Rijksdriehoekscoördinaten (Amersfoort/RD

New). It expresses in meters the distance to a central point in Amersfoort, the

Netherlands.

\section{ecosystem type classification:}

rivers (classification according to WFD):

$$
\begin{aligned}
& \text { altitude typology } \\
& \text { lowland: }<200 \mathrm{~m}
\end{aligned}
$$


size typology based on catchment area

small: $<100 \mathrm{~km}^{2}$, medium: $100-1000 \mathrm{~km}^{2}$

geology

siliceous

lakes (classification mainly according to WFD):

altitude typology

lowland: $<200 \mathrm{~m}$

site coding:

site coding available:

yes, numerical

number of digits:

5

example:

30-001

number of sites:

$100-1000$

comments:

Not all parameters were measured at each site and/or every year.

\section{Climate and environmental data}

\section{climate related data:}

available parameters per catchment:

daily air temperatures

data source: http://www.knmi.nl/over-het-knmi/about

winter and summer precipitation

data source: http://www.knmi.nl/over-het-knmi/about

evaporation

data source: http://www.knmi.nl/over-het-knmi/about

mean discharge

data source: Waterboard Vechtstromen

\section{environmental data:}

available parameters per catchment:

\section{catchment size}

data source: Waterboard Vechtstromen

available parameters per site: $\quad$ information on water uses (e.g., irrigation, fish ponds)

data source: Waterboard Vechtstromen

discharge

data source: Waterboard Vechtstromen

physico-chemistry data: total $\mathrm{P}$, ortho $\mathrm{P}$, nitrate, nitrite, total $\mathrm{N}$, ammonium, sulphate, chloride, magnesium, calcium, oxygen content, BOD5 (biochemical oyxgen demand), water temperature, $\mathrm{pH}$, chlorophyll, suspended solids availability of physico-chemical data, if there is more than one sample per site:

per sample

comments:

Depending on the site, one or multiple samples were taken during 2000-2012.

stressors influencing the sites:

reference sites available:

no 


\begin{tabular}{|l|l|l|l|l|}
\hline stressor & $\begin{array}{l}\text { restored sites } \\
\text { available }\end{array}$ & $\begin{array}{l}\text { data before/after } \\
\text { restoration } \\
\text { available }\end{array}$ & $\begin{array}{l}\text { stressor gradient } \\
\text { available }\end{array}$ & comments \\
\hline eutrophication & no & no & no & \\
\hline $\begin{array}{l}\text { hydrologic stress } \\
\text { (e.g. impoundment, } \\
\text { flow velocity } \\
\text { reduction, } \\
\text { hydropeaking, water } \\
\text { abstraction, flow } \\
\text { velocity increase) }\end{array}$ & no & no & no & \\
\hline
\end{tabular}

\title{
Biological data
}

\author{
biological data origin: \\ from sampling \\ specify project: \\ River Basin Management Plan - Waterboard Vechtstromen \\ organism group addressed: \\ fish, macro-invertebrates (Mollusca, Ephemeroptera, Odonata, Plecoptera, \\ Coleoptera, Trichoptera, Chironomidae), macrophytes
}

\section{Sample specifications/sample resolution}

\section{fish:}

\section{sample information:}

covered timeframe:

$2000-2012$

historical data:

no

palaeo data:

no

season:

spring, autumn

temporal resolution/frequency of sampling:

The temporal resolution depends on sampling location. Some locations were measured more frequently (yearly) than others (some only once).

time series data: yes

comments:

Mainly data between 2007-2011.

For more specific information and/or longer term information please contact waterboard Vechtstromen.

\section{taxonomic resolution:}

level:

species

percentage of species level data: 99

comments:

The percentage of species level data is an estimate. This dataset also contains fish sizes.

\section{taxonomic coding:}

taxalist according to:

reference(s):

\section{WNS code}

WNS stands for 'Waarnemingssoort' (type of measurement), a Dutch coding system. If needed the data can also be requested with latin species names for easier international use.

coding system:

WNS code

example:

\section{GASTACUL}

\section{sample specifications:}

type:

quantitative (abundance data) 
replicate samples: no

number of samples: $\quad 902$

specification of method(s) used for sampling and sorting:

Fishing, electrical fishing, seine fishing, sight.

reference(s): $\quad$ Bijkerk, Ronald and Marco Beers. Handboek Hydrobiologie. 1st ed.

Amersfoort: STOWA, 2010. Print.

http://handboekhydrobiologie.stowa.nl/Het_Handboek/Het_Handboek.aspx

sample type (e.g. habitat specific samples, composite samples etc.):

Composite samples.

\section{macro-invertebrates: sample information:}

covered timeframe:

$2000-2012$

historical data:

no

palaeo data:

no

season:

spring, autumn

temporal resolution/frequency of sampling:

The temporal resolution depends on sampling location. Some locations were measured more frequently (yearly) than others (some only once).

time series data:

no

comments:

This part of the data contains mainly data between 2007-2011.

For more specific information and/or longer term information please contact waterboard Vechtstromen.

\section{taxonomic resolution:}

level:

order, family, genus, species

percentage of species level data: 65

comments:

The percentage of species level data is an estimate.

\section{taxonomic coding:}

taxalist according to:

reference(s):

WNS code

WNS stands for 'Waarnemingssoort' (type of measurement), a Dutch coding system. If needed the data can also be requested with latin species names for easier international use.

coding system: WNS code

example: TUFICIAE

sample specifications:

type:

replicate samples:

quantitative (abundance data)

number of samples:

no

1296

specification of method(s) used for sampling and sorting:

Sampling is usually done by multi-habitat sampling with a standard macrofauna handnet. Sample sorting is done up to species level and lifestage. For specifics see the Handbook Hydrobiologie (Dutch).

reference(s): $\quad$ Bijkerk, Ronald and Marco Beers. Handboek Hydrobiologie. 1st ed.

Amersfoort: STOWA, 2010. Print.

http://handboekhydrobiologie.stowa.nl/Het_Handboek/Het_Handboek.aspx sample type (e.g. habitat specific samples, composite samples etc.):

Composite samples.

specific sample location (e.g. littoral, profundal, transect, shoreline, hyporheic zone, etc.):

Depending on the sampling site: littoral, profundal, and hyporheic zone. 


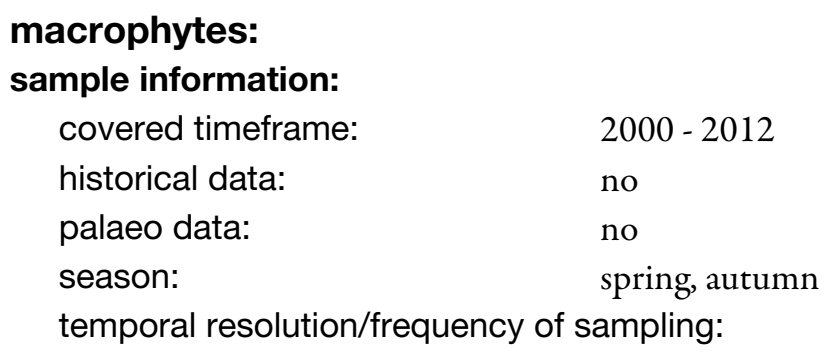

The temporal resolution depends on sampling location. Some locations were measured more frequently (yearly) than others (some only once)

time series data: yes

taxonomic resolution:

level: $\quad$ species, other

other taxonomic levels: type

percentage of species level data: 90

comments:

The percentage of species level data is an estimate. The types are: emerging, floating and submerged species.

taxonomic coding:

taxalist according to:

WNS code

reference(s):

WNS stands for 'Waarnemingssoort' (type of measurement), a Dutch coding system. If needed the data can also be requested with latin species names for easier international use.

coding system:

WNS code

example:

URTICDIO

sample specifications:

type:

semi-quantitative

replicate samples:

no

number of samples:

1280

specification of method(s) used for sampling and sorting:

Depending on the size of the sampling area the whole system or parts of the system are sampled according to the Handboek Hydrobiologie. Per sampled area the cover per species and species type are estimated (Tansley scale).

reference(s): Bijkerk, Ronald and Marco Beers. Handboek Hydrobiologie. 1st ed. Amersfoort: STOWA, 2010. Print.

http://handboekhydrobiologie.stowa.nl/Het_Handboek/Het_Handboek.aspx sample type (e.g. habitat specific samples, composite samples etc.):

Composite samples.

specific sample location (e.g. littoral, profundal, transect, shoreline, hyporheic zone, etc.):

Depending on the water body: Littoral, between 0-1 m depth, lake/river floor.

\title{
Other specifications
}

\section{GIS layers, shapes related to the dataset:}

\author{
availability of photos: \\ catchments, river-sub-basins \\ availability of maps: \\ no \\ quality control procedures: \\ yes \\ Were any quality control procedures applied to your dataset?
}




\section{Acknowledgements}

The data was provided by the Waterboard Vechtstromen and the Royal Netherlands Meteorological Institute (KNMI). This work was funded by the MARS project funded by the European Union under the 7th Framework Programme, Contract No. 603378.

\section{References}

Bijkerk, Ronald and Marco Beers, 2010. Handboek Hydrobiologie. 1st ed. Amersfoort: STOWA. Print. http://handboekhydrobiologie.stowa.nl/Het_Handboek/Het_Handboek.aspx

Waterboard Vechtstromen, 2015. Waterbeheerplan 2016-2021.7th October 2015. 